\title{
Another Model of Low Income Housing Tax Credit Development: Building Housing and Building Capacity
}

Michael R. Diamond

Georgetown University Law Center, diamondm@law.georgetown.edu

This paper can be downloaded free of charge from:

https://scholarship.law.georgetown.edu/facpub/264

Michael Diamond, Another Model of Low Income Housing Tax Credit Development: Building Housing and Building Capacity in AFFORDABLE HOUSING AND PUBLIC-PRIVATE PARTNERSHIPS (Nestor M. Davidson \& Robin Paul Malloy eds., Farnham, U.K.: Ashgate Press 2009)

This open-access article is brought to you by the Georgetown Law Library. Posted with permission of the author. Follow this and additional works at: https://scholarship.law.georgetown.edu/facpub

Part of the Housing Law Commons 


\section{GEORGETOWN LAW Faculty Publications}

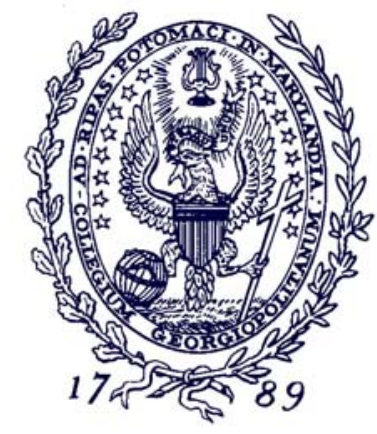

February 2010

Georgetown Public Law Research Paper No. 10-08

\section{Another Model of Low Income Housing Tax Credit Development: Building Housing and Building Capacity \\ in}

\section{AfFordable Housing And Public-PRIVATE}

PARTNERSHIPS (Nestor M. Davidson \& Robin Paul

Malloy eds., Farnham, U.K.: Ashgate Press 2009)

\section{Michael Diamond}

Professor of Law

Georgetown University Law Center

diamondm@law.georgetown.edu

This paper can be downloaded without charge from:

Scholarly Commons: http://scholarship.law.georgetown.edu/facpub/264/

SSRN: http://ssrn.com/abstract $=1558479$

Posted with permission of the author 


\title{
Chapter 4
}

\section{Another Model of Low Income Housing Tax Credit Development: Building Housing and Building Capacity}

\author{
Michael Diamond
}

This publication derives from a workshop whose theme was "Affordable Housing and Public-Private Partnerships: The Intersection of Housing, Property, and Real Estate." My particular concern at the workshop and in this chapter is the intersection of affordable housing, poverty and community. I am also interested in the ways in which law and lawyers have addressed and, in the future, might address these issues. As has been amply discussed over the years, poverty is the result of many factors and is composed of many elements.' Lawyers have long been prominent in the battle against poverty but the law itself has, inadvertently or not, been as much a cause as a cure for the problems of poverty. I believe that to combat poverty and to alleviate at least some of its insidious effects, lawyers must take a broader view of the nature of poverty and of their own role in the struggle to combat it.

I have focused on housing as a core element in poverty because housing is central to people's lives and affects many aspects of their existence beyond the mere provision of shelter. ${ }^{2}$ Among these, housing creates the possibility of wealth creation, provides the situs for family and social life, affects one's sense of identity, health, and well-being, and has a major impact on educational prospects and attainment. ${ }^{3} \mathrm{I}$ have been interested in housing for all of these reasons, but my interest here is about the political possibilities of housing. By this I mean the opportunity housing offers to residents for organization, for capacity building, for participation in civic activities, and for social and political interaction. ${ }^{4}$ These opportunities offer the potential to create and maintain community institutions that

1 Sheldon Danziger \& Peter Gottschalk, America Unequal 92-110 (1995). The authors point to the shift towards single female headed households, a slow rate of economic growth between the 1970 s to 1990 s, and the slow rate of increase in the mean income level as significant factors of increased poverty.

2 J. Peter Byrne \& Michael Diamond, Affordable Housing, Land Tenure and Urban Policy: The Matrix Revealed, 34 Fordham URB. L.J. 527, 527-31 (2007) [hereinafter Byme and Diamond, Matrix Revealed].

3 Id. at 527.

4 Id. at $574-80$. 
can acquire and wield power on an ongoing basis. ${ }^{5} \mathrm{I}$ believe that such institutions must be in the forefront of the struggle against poverty and subordination and are essential to the success of that struggle.

This view of housing as a central element in the struggle against poverty has motivated me over the years to explore the idea of preserving affordable housing for low income residents through tenant ownership of that housing. Through tenant ownership, the residents, both current and future occupants of the property, can control its destiny and therefore, in a not insignificant way, a part of their own. Through ownership of their building they can, to a degree, control costs, prioritize needs, select incoming co-owners, and, in the process, recognize and develop skills in themselves that may be transferred into other areas of their lives. Moreover, through their ownership, they may serve as symbols of what is possible and, in a more immediate sense, have an impact on the conditions in the community in which they reside. ${ }^{6}$

Of course, to make tenant ownership work requires support from many quarters including, not insignificantly, from the government, both on the local level and nationally. While many states and local jurisdictions actively support affordable housing and some support the idea of tenant ownership, ${ }^{7}$ the federal government has been less supportive. In fact, the federal government is no longer in the business of producing affordable housing. ${ }^{8}$ While the federal government used to produce significant numbers of public housing units, the public housing program had fallen into disuse in many areas and into disrepute in the public's consciousness. This withdrawal from the production arena has resulted, in part, in the severe shortage of adequate, affordable housing for low income families.

Instead of direct production, for several years now the federal government's housing policy on the supply side has been to encourage private enterprise to produce affordable housing. ${ }^{9}$ One of the main aspects of this approach has been

5 Id. at $596-601$.

6 Michael Diamond, Community Economic Development: A Reflection on Community, Power and the Law, 8 J. SMall \& EMERging Bus. L. 151, 166-7 (2004).

7 See, e.g., the Illinois Tenants Union, http://www.tenant.org/about.htm (last visited September 12, 2008); the National Alliance of HUD Tenants, http://www.saveourhomes. org (last visited September 12, 2008); and the Housing Crisis Center, http://www.hccdallas. org/index 1.html (last visited September 12, 2008).

8 Kent W. Colton, Housing In the Twenty-First Century: Achieving Common GROUND 220-21 (2003).

9 On the demand side, there are various subsidy programs, the most prominent of them, other than the income tax deductions for homeowners of mortgage interest and real estate taxes, being the Housing Choice Voucher program. This program was formerly known as the $\S 8$ program. It subsidizes recipients by providing the difference between 30 percent of the recipient's income and the rent for an acceptable unit, so long as the rent does not exceed a federally set cap. 
the Low Income Housing Tax Credit program (LIHTC). ${ }^{10}$ Through this program more than 1.4 million units of low income housing have been built or renovated between 1987 and $2004 .{ }^{11}$ Low income residents often benefit from this program by obtaining decent housing at affordable rents. Depending on the sponsor of a particular development, the residents might also have the opportunity to obtain various social services and amenities such as an after-school program or a computer lab. Rarely, however, do residents participate in the decision-making concerning the property and its operation. My goal in this chapter is to offer a model for giving residents significant involvement in every aspect of the development and operation of a tax credit property. I will argue that doing so is beneficial to all concerned. Moreover, while the context for the model is a tax credit development, I will argue that it is, in many ways, a usable model in several other situations.

In the first part of this chapter I will describe the tax credit regime and the typical tax credit ownership vehicle, a limited partnership comprised of investors as limited partners and a developer, either non-profit or for-profit, as the general partner. In the second part, I will present a different model for the ownership of the property in which the residents of a building that will undergo tax credit renovation participate in all phases of the project. The third part will include a discussion of the benefits to the residents and, indirectly, to the community in which they live, to be derived from resident participation. In the conclusion, I will suggest the possibility of expanding the model to areas other than tax credit transactions with the expectation that the benefits of resident participation can be obtained in these other areas as well.

\section{The Tax Credit Program}

Section 42 of the Internal Revenue Code was added in 1986. It essentially offers tax credits, that is, a dollar for dollar reduction of a taxpayer's tax liability, in exchange for private investment in the construction or redevelopment of affordable housing. ${ }^{12}$ There are two different programs under which an owner of property may be awarded these credits. ${ }^{13}$ As I mentioned above, the LIHTC program has produced a total of more than 1.4 million units of affordable housing since 1987, by far the largest federal

1026 U.S.C. $\S 42$ (2008). The program offers taxpayers significant tax benefits in exchange for their investment in low income housing development.

11 HUD USER Data Sets, U.S. Department of Housing and Urban Development, Low-Income Housing Tax Credits, http://www.huduser.org/datasets/lihtc.html (last visited November 16, 2007).

12 Housing is considered affordable if a family would spend no more than 30 percent of their income on housing. See Affordable Housing Needs 2005: Report to Congress, 2007 U.S. Department of Housing and Urban Development, Office of Policy Development and RESEARCH 23.

1326 U.S.C. $\S 42$ (b) (2008) provides for a 9 percent credit and a 4 percent credit. The 9 percent credit is available for otherwise eligible projects that are not federally subsidized. The 4 percent credit is for projects that have other federal subsidy. For this purpose, 
affordable housing development program since the inception of Low Income Housing Tax Credits. The operation of this program involves great complexities that are largely beyond the scope of this chapter. What I do want to explore, however, is the effect on a tax credit development and on the residents of such a development of the ongoing, in-depth involvement of those residents in the planning and implementation of the project and the subsequent operation of the renovated building.

Since tax credits are allocated only to owners of property, the form of ownership must be one that permits tax write-offs to pass through directly to the business owners. Most of the investors are individuals or companies that are not otherwise involved with the affordable housing business, and will not be involved in the planning, implementation or operation of the project in which they invest. They therefore demand, as a prerequisite for investing, protection from the liabilities that might arise from the construction and operation of the property. The ownership vehicle that has traditionally been chosen is a limited partnership (although today a limited liability company would appear to be the more efficient vehicle). ${ }^{14}$ The developer would be the general partner and manager of the project and the investors would be the limited partners with no role in the project's management. The general partner's liability would be unlimited but the limited partners enjoy limited liability. ${ }^{15}$ The developer typically receives no more (and often less) than 1 percent of the profits, losses, and credits from the venture while the investors will receive the balance, typically 99.9 percent.

Because of the tax risks associated with these projects, ${ }^{16}$ the investors will require that the general partner be experienced in real estate development in general and in tax credit development and operations in particular. Moreover, they normally require that the developer provide them with financial guarantees against losses that may occur due to the recapture of the credits. Thus, in addition to being experienced, the general partner must have financial resources sufficient to protect the investors in the event that the general partner's management results in unexpected tax liabilities for the investors.

The financing of a tax credit development involves, in addition to the normal equity and debt calculation typical in any proposed real estate development, a

financing with tax exempt bonds qualifies as federally subsidized and the use of such bonds generally accompanies the 4 percent credit.

14 A limited liability company offers all the tax and liability features desired by the investors along with great flexibility in governance. Nevertheless, attorneys for investors are often uncomfortable with this relatively recent form of doing business and often insist upon the more familiar limited partnership. As we will see in the second part of this chapter, when a tenants' association is involved in the ownership structure, that discomfort can lead to a much more complex ownership entity.

15 So long as a limited partner does not engage in the management of the project, his or her liability will be limited to the amount he or she invested.

16 The main risk is the recapture of previously claimed credits together with the interest and penalties associated with the resulting underpayment of taxes for the years in which the recaptured credits had been claimed. 
calculation of the amount that might be contributed by investors seeking tax write-offs. The amount of write-off, and thus an approximation of the amount of capital that might be invested, is calculated by determining the eligible basis of the property, ${ }^{17}$ which will establish how much credit will be available to investors, ${ }^{18}$ and then multiplying that number by the then current market rate for credits. ${ }^{19}$ This will tell the developer approximately how much he or she will receive from the sale of the credits. ${ }^{20}$ Since the contribution by investors to obtain access to the credits is an equity investment, it need not be repaid to the investors and works as a reduction of the amount needed to be borrowed to finance the project. That, in turn, results in lower financing costs. Developers, therefore, will evaluate the use of tax credits for a project by determining whether the net inflow of dollars from investors will make a financially viable project more profitable, permit a greater degree of rehabilitation than could otherwise be had with conventional financing, or make a financially questionable project feasible. ${ }^{21}$

The agreement between the investors and the developer will be memorialized in a limited partnership agreement. The agreement limits the general partner's activities to those that are consistent with the LIHTC guidelines and sets out the organizational parameters of the partnership. The negotiation of this document is important because, in many ways, it can allocate control of the operations of the development by restricting the general partner in ways that the limited partners could not, without jeopardizing the limited liability status of the investors, once the partnership is created. It is through this agreement that the residents, acting

17 The basis includes the cost of the building plus certain other depreciable or amortizable costs times the percentage of the project that will be used to house eligible residents.

18 For example, if the eligible basis of a property is $\$ 10,000,000$, the 4 percent credit program (there is also a 9 percent program) would give the investors approximately $\$ 4,000,000$ of credit over ten years available in installments of $\$ 400,000$ per year. If investors were paying $\$ 0.85$ per dollar of credit, they would pay $\$ 3,400,000$ for the $\$ 4,000,000$ of credit.

19 There is a market for credits that functions as any other market. To the extent that there is a great supply of comparable investments, the demand for credits would fall and so would their price. Recently, the price for credits was more than 95 cents per dollar of credit. An interesting question is whether the participation of residents, thereby deviating from the standard model of tax credit deals, affected the price investors were willing to pay for the credits in this deal. This is a question to which I will return later in this chapter.

20 There are other calculations, such as what percentage of the units will be tax credit eligible and what the actual rate of credit will be for the investors that affect the final amount to be contributed.

21 Investors, of course, will calculate the value of the potential tax credits and against the risks of losing the credits against the risks and rewards of other available investments. This will determine whether the individual investor is interested in a deal and, if so, the amount he or she is willing to invest in the activity. The calculation is made without regard to the return of the investment capital. 
through a tenants' association, can have a major influence on the structure and operations of the project.

\section{Tenant Involvement in the Development Process}

I and others have written elsewhere about the significance of participation by low income residents in the life of their communities and in their buildings. ${ }^{22}$ The same benefits of participation apply to projects financed with tax credits. The involvement of residents has the potential to enhance the physical development of the property, its ongoing operations and to increase the capacity and social capital of the residents. Nevertheless, very few tax credit projects involve residents in a significant, much less an ownership, capacity. In this section I will discuss resident involvement in the planning of a project, their participation in its management, and their ability to obtain title to the property at the expiration of the tax credit compliance period. ${ }^{23}$ In discussing these issues, I will also explain what I think are the benefits to the developer in agreeing to the residents' proposal.

\section{Project Planning}

Several years ago, a tenant in a building in the District of Columbia received a notice from the building's owner that he intended to sell the building and had a buyer ready to purchase, subject only to the residents' rights pursuant to the District's Tenant Opportunity to Purchase Act (TOPA). ${ }^{24}$ TOPA requires that when an owner of residential rental property in the District desires to sell the property, the owner must give the residents a bona fide opportunity to purchase it. ${ }^{25}$ The notice sent by the owner informed the residents of his intent to sell, gave information about the third party buyer and the contract the owner had with the third party, and gave the residents the opportunity to purchase the building. The building has 136

22 See generally U.S. Department of Housing and Urban Development, Community Building in Public Housing: Ties that Bind People and Their Communities (1997); Byrne and Diamond, Matrix Revealed, supra note 2; Michael Diamond \& Aaron O'Toole, Leaders, Followers and Free Riders: The Community Lawyer's Dilemma When Representing NonDemocratic Client Organizations, 31 FordhaM URB. L.J. 481 (2004); Duncan Kennedy, The Limited Equity Coop as a Vehicle for Affordable Housing in a Race and Class Divided Society, 46 How. L.J. 85 (2002); Georgette C. Poindexter, Who Gets the Final No? Tenant Participation in Public Housing Redevelopment, 9 CoRnell J.L. \& PuB. Pol'y 659 (2000).

23 As a practical matter, there must be tax credit compliance for 15 years from the time the property is put into service under the tax credit program. After that, the limited partnership disposes of its asset, the property, and dissolves. The property normally then goes to the developer/general partner based on a formula established in the partnership agreement.

24 D.C. Code $\S \S 42-3404.02$ et seq. (2001).

25 D.C. Code $\$ \S 42-3404.02$ (a) (2001). 
units and was selling for $\$ 6.5$ million. It is in a neighborhood that had traditionally been African American with a mix of working class and lower income residents. The neighborhood, however, was rapidly gentrifying due to the construction of a new Convention Center and the amenities that would accompany its completion, particularly a hotel, restaurants, and shops that would cater to those attending events at the Center. Many of the long-term residents of the neighborhood and of the building feared that they would be forced out of their homes.

When the residents received the notice, they organized a tenants' association and hired an attorney. Together, they reviewed their options under the statute. The association could purchase the building itself and develop it as an affordable rental, a cooperative or a condominium. It could form a partnership with a third party developer of its choice and assign its right to purchase to the developer in exchange for various concessions, such as guaranteed rents, participation in management or relocation benefits, that they could agree upon in advance. Finally, it could sell its rights for cash and its members could either leave the building or remain as renters under a new owner. The latter choice was not really considered because the association had as one of its goals the preservation of affordable housing in the neighborhood and the ability of any resident who wanted to remain in the building to be able to do so.

The resident association made an initial decision to pursue their opportunity to purchase the building. Doing so preserved their rights but did not commit them actually to complete the purchase. The attorney presented the association with information about the process of purchasing the building, about available financing, about third party developers, and about operating a building once it was purchased. The residents, who typically earned 60 percent or less of the area median income, had no prior experience with purchasing property and were disconcerted by the price asked by the owner. They feared they could neither raise the required financing nor operate the building should they be able to acquire it. Moreover, the building would need millions of dollars of renovation in order to be brought into compliance with the local housing code and made more modern and efficient. When all was said and done, the residents were looking at a project that would probably cost between $\$ 15,000,000$ and $\$ 20,000,000$, numbers that were beyond comprehension for many of them.

They decided that their best chance to develop the property in a manner that preserved affordability and gave them the opportunity to participate meaningfully in the process was to work with a developer. They interviewed several large and well-respected non-profit developers with experience in affordable housing. In conversations with these developers, the idea of using Low Income Housing Tax Credits was proposed. The use of the credits would bring in much needed equity to reduce the amount of debt the project would have to carry. This, in turn, would 
lower the financing costs of the project. The tradeoff for the influx of equity, however, would be the loss of some control by the residents. ${ }^{26}$

After a great deal of debate and consideration, the residents decided to go ahead with a development using tax credits. While they were concerned about the loss of control, it was, at least in part, their concern about their inability to manage the project that brought them to the third party developers in the first place. Moreover, the loss of control need not be complete. While tax credit projects typically did not have significant resident involvement in their planning or implementation, they also typically did not have the reality of residents being able to control who could purchase the property. The leverage provided by TOPA concerning the acquisition of a desirable piece of property allowed the residents to negotiate a high degree of involvement in the development. With this possibility at the forefront of their strategy, the residents narrowed the field of potential partners and began negotiating with them. They eventually made a choice and began the process of creating the relationship they desired.

A word would be useful here about the motivations of the developer. There are several reasons why the developer would go along with this, admittedly highly unusual and, to a great extent, more problematic, deal. While I do not know how the developer prioritized these reasons, let me suggest a few, in no particular order, that the developer would consider important. As I mentioned earlier, the developer was a non-profit organization. Its mission was to preserve affordable housing and this project provided an opportunity to preserve a significant number of affordable units from what otherwise would have become an upper income condominium project in a rapidly gentrifying neighborhood. Moreover, tax credit developments typically offer developers a significant fee for their efforts, generally just under 15 percent of the total development costs of the project. In this project, because of TOPA, if the developer wanted to be involved, it had to make concessions to the residents or they would go elsewhere to obtain a developer.

\section{Setting the Terms of the Deal}

The residents had several goals they wanted to achieve in any agreement to assign their right to purchase the building. Among them was the desire to participate in the planning of the project, to be engaged in its management, and to be able to have title to the building at the end of the compliance period. These goals served two overriding purposes: to have an improved yet affordable living situation and to gain capacity as individuals and as a group. As a consequence of gaining capacity, the residents hoped to have an effect on their personal lives, their building, their

26 As mentioned earlier, the investors in a tax credit deal would require that there be an experienced developer serving as a general partner and that the developer have control of all issues pertaining to the continued eligibility to receive credits. That meant that the residents would have to give up a good deal of authority to the developer if they wished to pursue a tax credit development. 
neighbors, and their community. They hoped, in other words, to create a durable institution that would be both a bellwether of resident rights and a model of what a determined group can achieve. ${ }^{27}$

On the other side of the table, the developer's goals were to produce affordable housing, a goal it had in common with the residents, and to do so efficiently and in compliance with the tax credit rules, particularly since the developer would be required to guarantee to investors that they would receive the expected credits. The developer also desired to make money from its development and operation of the project. It feared that tenant involvement would jeopardize these goals by slowing the process, making it more expensive, and scaring investors into investing less capital or worse, not investing at all. ${ }^{28}$ To add to its concern, the developer had no experience with resident groups as partners. While it had good relations with residents in buildings it owned and operated as rentals, it never had to deal with residents as business equals.

\section{Negotiating the Partnership Agreement}

The developer had expressed a willingness in principle to form a partnership with the resident association but it had not really considered the dimensions of that relationship. Nevertheless, it was surprised at the expectations of the residents and somewhat resistant to them. To begin with, the residents wanted their association to be a co-general partner with the developer in the limited partnership that would own the property. In that role, while they were willing to give the developer final say on any issue that affected the provision of the tax benefits to the investors, on other issues it wanted considerable input, and on some, total control.

For example, the residents wanted to, among other things, help to structure the financing, participate in the renovation planning, and pick the management company. They also wanted to be involved in tenant selection (provided the potential tenants were tax credit eligible), participate in planning social and educational programs for residents, develop house rules, and participate in selecting a security company. Due to the reluctance of the developer to engage so deeply with the residents, the negotiation of the agreement was difficult and time-consuming. It involved an education for both the resident leadership and the developer. The developer learned that the residents had capabilities and insights that were valuable and, at least to the developer, totally unexpected. It also learned of the residents' commitment to the project and to participating in it, and of the hard work the residents were willing to put into completing it and making it successful. In fact, meetings took place regularly, often several times a week, until a deal was hammered out.

The education obtained by the residents was multifaceted. An obvious outcome was that they began to learn about housing development and finance. They

27 Byme and Diamond, Matrix Revealed, supra note 1, at 596-601.

28 The developer guaranty helped ease any concerns the investors might have had about the degree of resident participation. It left the pricing of the credits at essentially what it would have been in a deal without the resident participation. 
learned how hard it is to develop and run a successful project and of the skill and commitment of the developer. They learned that their homes were also the main asset of a business that they would help to operate and the heavily intertwined nature of these factors. More subtly, however, the residents learned about their own capacity and about partnership in a sophisticated undertaking.

As these lessons were being learned, often after acrimonious interactions, the relationship settled into a more trusting and productive one. A partnership agreement was negotiated with compromises acceptable to each party. For instance, the residents participated fully in all aspects of the development and assisted in structuring the financing. The developer retained final say only to the extent that the tax credit regulations or significant budgetary constraints were involved. Renovation plans were to be jointly developed and monitored. The residents interviewed architects and general contractors and participated in the negotiation of their contracts. The residents would pick the management company from among a group acceptable to the developer. The residents would also be responsible for preparing house rules.

Another major element of the partnership agreement involved the disposition of the property after the end of the tax credit compliance period. At that point, the limited partner investors would want to terminate the partnership and move on. The residents wanted the building back. The developer was the least certain element. It was in the business of buying and operating affordable housing and this property was both sound and in a gentrifying neighborhood. Its value could be expected to increase over time. On the other hand, the developer had a mission of preservation of affordable housing and the development of resident capacity.

The resolution of this issue was very favorable to the residents. At the end of the compliance period, and the liquidation of the partnership, the resident association would take title to the building in exchange for its assuming the existing debt on the property, paying the transaction costs of liquidating the partnership and paying any exit taxes, most likely to be capital gains, incurred by the other partners. Thus, for what would amount to a relatively small outlay of cash, which could be obtained by refinancing the debt on the property or by taking a second mortgage, the residents could secure a very valuable asset. Their goal would be to convert the property to some form of homeownership, a cooperative or a condominium, that would preserve affordability while giving individual residents a financial stake in the property. ${ }^{29}$

29 Interestingly, the developer has recently changed its business model. It is no longer willing to permit subsequent resident groups to obtain the property on the same terms as described herein. It has said that in order to preserve its own capital base, it needs to own the property. When faced with the prospect that tenant groups using TOPA to initiate tax credit projects would not work with this developer, the developer modified its position to suggest that it would be willing to discuss a split of the equity between the tenant association and the developer (that is, the association would have to pay more to obtain the building with 
The final element of the agreement was the splitting of the developer's fee. The total fee was substantial, being a total of 12 percent of the acquisition cost and 15 percent of the total development cost other than acquisition. ${ }^{30}$ The parties negotiated an 80/20 split of the approximately $\$ 3$ million fee. The fee would be paid over several years as the equity from the investors was paid in. ${ }^{31}$ The residents decided that to protect its share of the fee for future use, particularly the need for funds at the end of the compliance period, they would set up a fund in the nature of a trust. They created such a fund that was to be managed by a financial professional who would invest the principal in a prudent, income-producing manner. The association provided for its ability to use a limited amount of the annual income of the fund to cover various current expenses. The balance would be held for use when the property was transferred to the association.

\section{Developing the Property}

Once the agreement was signed, the parties moved on to the process of developing the property. They worked on creating a pro forma for the development with the goal of maximizing the eligible basis of the property. The higher the basis, the more credit would be available and the greater the capital contributions of the investors. The parties found various ways to increase basis including increasing the level of renovation to be done. Of course, the higher the cost of the transaction, the higher the rents would have to be to support the project. Also, the higher the cost, the higher the fee to the developer. This created a series of conflicts that had to be resolved by the parties. A resolution could be found through careful planning of the project's financing.

The residents, along with the developer, decided to seek funding from various sources, including heavily subsidized loans from the District of Columbia's Department of Housing and Community Development (DHCD) ${ }^{32}$ Of course, there would be the equity contribution of the investors and, given the tax credit program

the excess going to the developer) or the developer would have to be guaranteed a new developer's fee for any redevelopment of the property after the compliance period expires.

30 This is the maximum percentage allowed by the LIHTC rules and is the standard fee taken by developers of such projects. The percentages are the same regardless of whether the project involves a large dollar amount or a small one. Therefore, the fee does not necessarily correspond to the amount of work a developer puts into a particular project. As there is a potential bonus above the cost of labor, overhead, and profit and risk factors, the surplus may add significantly to the cost of the project, thereby increasing tenant rents beyond what is necessary to keep developers interested in undertaking such deals.

31 Investor contributions usually come in installments as certain benchmarks are met. The entire contribution would be paid by the time the buildings had been substantially renovated, usually a period of several years after the tax credit deal was finalized with the investors.

32 This agency is the conduit for the U.S. Department of Housing and Urban Development's (HUD) Community Development Block Grant and HOME funds. It also administers the District's Housing Production Trust Fund program. 
they intended to use, there would be tax exempt municipal bonds issued by the District's Housing Finance Agency. ${ }^{33}$ The bonds, though carrying an interest rate that was below market, were still a relatively expensive item. The DHCD loans can carry very low interest rates, occasionally as low as half of 1 percent over 40 years. If such a loan were available and was blended with the bonds and equity, the overall effective interest rate on the total project would be manageable. Nevertheless, the parties also sought to acquire or maintain existing governmental subsidies such as Section $8^{34}$ rent subsidies and Section $236^{35}$ mortgage interest reduction payments. Each of these efforts was ultimately successful, allowing for a total development cost of about $\$ 22$ million but retaining affordability for all residents. Of the 136 residents who lived in the building at the start of the process, more than 125 remained when the process was completed.

The resident association engaged in a variety of other activities such as interacting with the architect, the contractor, various financial institutions, and, of course, with the developer. Partnership meetings between the developer and the association occurred weekly, while development team meetings, including the residents, their lawyers, the contractor architect, and the developer, usually occurred every two weeks. Other meetings occurred as needed (but the need was constant). The members of the board made and followed through on a heavy commitment of time and energy, which commitment continued long after the project was completed. For example, there were regular meetings with the developer and the management company concerning the operation of the building. There were also regular meetings with the residents to keep them informed of what was going on in the building and to get their input on decisions that needed to be made about operations and ongoing improvements.

\section{Benefits Derived from Resident Participation}

The benefits that have been derived from resident participation in the development of this project can be categorized into three main areas: improvement of building conditions; improved conditions in the community; and personal development. While there have been significant benefits in each of these areas, there have also been several unfavorable aspects of that participation. In this section, I will discuss these aspects and attempt to educe some lessons for subsequent transactions.

33 The agency issues the bonds to investors, often the same investors who purchase the credits, and uses the proceeds from the bond sale to issue a mortgage to the property owner.

34 See 42 U.S.C. $\$ 1437 f(a)(2000)$.

35 See 12 U.S.C. $\$ 1715 \mathrm{z}-1$ (2000). 


\section{Improvements in the Building}

Once the relationship between the parties was established, they turned their attention to the physical redevelopment of the building. The building had obvious needs such as a new roof, upgraded electrical and plumbing systems, and more modem heating and cooling. There were a variety of other needs of the residents beyond those required for health and safety or code compliance. For example, the residents desired a community area where they could hold tenant-wide meetings, celebrations, educational programs, and community events. They designed an area on the lower level that would accommodate a large crowd and built in a kitchen, restrooms, and storage space. They also created a secure first floor office for the tenants' association where the board of directors could hold meetings and where corporate records could be kept. Residents also helped to design the facade of the building and its entry area.

The residents were also concerned about the disruptions that would be caused by the construction activities at the property. The residents and developer had decided that construction would go on with residents in place. This decision had been reached due to the residents' desire not to have to move out of the property and then to move back and by the cost savings for the project of not having to pay for relocation and for excess rent payments elsewhere. In order to make this disruption palatable, the residents and developer created a plan in which development would occur on a floor at a time. The residents and developer created a hospitality suite on the lower level where the community room had been built. They installed chairs, couches, tables, computers with internet access, televisions, and VCRs, provided books and games, and made the space available to tenants whose floor was being worked on at the time. The construction plan was to do all in-unit work on a tight schedule so that unit functions such as electricity and plumbing, heating and cooling, would not be available during the day but would be restored each evening when the tenant returned to the unit. While the process was inconvenient and messy (and engendered a good deal of griping), it was completed successfully with a significant cost saving to the project.

As life in the building stabilized, the residents developed a set of house rules, rules for the day-to-day life of the building. They provided, among other things, regulations about pets, noise, access to the community room, and guests. They imposed penalties for violations that escalated from warnings to expulsion, and became more severe depending on the gravity or frequency of the violation. These rules were developed by the association's leadership after consultation with the general membership. When a final draft was ready, it was presented to the membership for a vote. The rules have been incorporated by reference into the leases in the building and are binding on all tenants and their guests.

As time went on, the residents had problems with the management company and the security company. In each case, the personnel of the management and security companies were not doing their jobs and were not treating the leadership of the tenants' association as a part of the ownership structure of the property. After several meetings with the leadership of the tenants' association, the non-profit 
developer, and executives of each of the companies, the management company created a new set of operating guidelines for dealing with the tenants' association and the security company was replaced.

Security, however, continued to be a major problem. While the neighborhood was gentrifying, there were still significant elements of gang and drug activity in the area. This was a particular problem in the building, in part because higher income buildings in the neighborhood could afford a greater number of full-time security personnel on the premises. Thus, the drug sales and violence gravitated to the less well-secured buildings. The residents were particularly concerned about the activity in and around the building. They pressured management to identify those residents letting unauthorized people into the building or who were engaged in illegal activity, and to proceed against them in court. They pressured the security company to do identity checks of everyone who entered the building. Picture ID cards were given to residents and guests had to identify themselves with a picture ID, say who they were visiting, and sign in.

This latter requirement caused some negative response by some of the tenants who did not want to show IDs to the security personnel. Several building-wide meetings were held to address these concerns, with many residents wanting even stronger measures imposed to restore safety and order to the premises. The residents then started interacting with the Metropolitan Police and the U.S. Attorney's office to get their assistance in resolving the security problems. They were successful in having the police and U.S. Attorney attend meetings at the property and beef up patrols in the area and in the building itself.

These efforts have helped to keep out strangers who used the building to buy, sell or use drugs, and for the purpose of general loitering. They did not, however, completely solve the problem. The residents then sought to have the elevators and the entry to the first floor apartments (which gave access to the stairways in the building) protected by swipe card access from the entrance area of the building. Again over objection by some residents, these changes were implemented after building-wide meetings were held to discuss and, ultimately, to approve the modifications.

The results of the efforts by residents were to create a desired renovation in a way that met residents' needs; to improve the day-to-day life in the building; to add social and service amenities to the property; and to improve the security of the residents. These improvements were the result of resident initiatives. They were accepted, even welcomed, by the developer in part because of the merits of the initiatives but also because of the contractual role played by the residents. The role gave them the right not only to propose initiatives but also to have them implemented. This right, in turn, gave them greater access to and involvement with the developer who came to recognize the resident association as a true partner in the operation of the building. 
There have also been several beneficial effects for the local community as a whole. An obvious one is that the greater involvement of the local law enforcement agencies in the life of the building has had a spillover effect for the area surrounding the building. More police patrols and greater involvement in the neighborhood has led to fewer incidents and a lower level of violence. Moreover, other property owners and tenants' associations as well as local community groups have observed the improvements at the property and sought to become involved in a broader effort to reduce crime and increase safety for their buildings and for the community as a whole. This has led to collaborations between several tenants' associations and building owners over a variety of issues in the community.

This collaboration was initiated by a suggestion made by the leader of the tenants' association during one of the regular meetings with the developer and management company. Each participant in that meeting agreed to make contact with other entities in the neighborhood (for example, other buildings managed by the management company or owned by the developer and local organizations and tenant groups) to begin to meet to discuss neighborhood issues. They also agreed to contact the local city council member and invite him to meet with the local residents to discuss these issues.

The resident association has also established an after-school program and a summer camp for children in the building. While it is currently limited to the children of residents, the plan is either to open the programs up to other neighborhood children or to assist other buildings in creating similar programs, and to establish a collaboration among the different buildings and programs in order to enrich all of them. These programs have worked well and are staffed by a combination of professionals (whose salaries were budgeted in the original development plan) and volunteers from the building. In addition, there is a computer lab and a seniors program that, again, are planned to be expanded or replicated in neighboring buildings. Finally, the community room in the building has been used for meetings of organizations engaged in alcohol and substance abuse self-help. These programs have been opened to a wider community participation and are not limited just to residents of the building.

\section{Conclusion}

To a great extent, it is too soon to tell what effect the resident association will have on the neighborhood as a whole. It may even be too soon to make a definitive prediction on the benefits to be derived by the building and its residents. Preliminary indications, however, are positive. This is not to say that there are not problems, often significant ones, in the building. For example, there is always a concern for the economics of the situation. The goal is to provide affordable housing and that means keeping the rents within the means of the residents. This is in some conflict with the ambitious nature 
of the programs and social services that the residents want for themselves and their neighbors. The association, in conjunction with their developer/partner, has begun applying for grants to accomplish some of their goals without straining their budget.

There is also the problem of resident disinterest or free-riding. Not enough people are fully engaged and many others are not engaged at all. For the time being, there is a critical mass sufficient to carry out the program design, but will there be adequate leadership when the current group of leaders moves on? Can a second or subsequent generation of leaders have the same commitment to participation as those who went through the development process? Do they need that level of commitment or, now that the major activities have been undertaken and major goals accomplished, is a lesser level of dedication sufficient?

Interestingly, and in some conflict with the previous observation, there is a problem of fictionalization within the group. There are two groups vying for power within the building and, while each has the best interests of the group in mind, they are very different in approach. Nevertheless, much of this situation is based on personality. Leadership is very visible in the building and in the community. Because of this visibility, the leaders have drawn fire from other residents and neighbors. Some have claimed that the leadership is now the owner of the building or that leaders have misappropriated funds. While neither allegation is true, these and other claims take their toll on the leaders who occasionally wonder whether the successes are worth the time and trouble associated with them. Burn out in such an intense activity is a real concern.

Beyond these problems, however, stands a fully renovated building with significant tenant input concerning all aspects of management. There has been preservation of 136 units of affordable housing in a very hot downtown housing market. In addition, there is a large body of residents who have grown in terms of capacity, self-confidence, and social capital. This has been accomplished by creating a hybrid model between traditional rental housing and tenant ownership. It is a model that has the potential for significant rewards, albeit at some costs. It is also a model that can be replicated in situations other than tax credit deals. Two such situations come immediately to mind.

The first is a situation where the sponsor of affordable rental housing has a mission-driven position that supports tenants. Many such sponsors already involve residents in choosing and providing various social services on the property. This relationship could easily be expanded, by contract or otherwise, into giving tenants a role in management. The role might be merely advisory or, in some cases, might be decisional. The effects of this type of involvement are to create better understanding and a tighter bond between residents and sponsor and, in many cases, I believe, a better run building.

The second area in which this model might be utilized is a bit more contentious. I have speculated for many years about the benefits of using such a model in the context of settling landlord-tenant matters when one of the parties to the action is a tenants' association. In many such cases, where a landlord is seeking rent and the residents have withheld it because of poor conditions in the building, the case is 
settled with the landlord promising to make repairs and the residents paying over some of all of the withheld rent. My speculation goes to what are the possibilities of including some tenant involvement in management as part of the settlement.

Of course, this possibility would require a motivated tenant group and ongoing professional assistance. Both of these prerequisites are far from certain elements of any situation. Unlike tenant ownership situations, the residents in a landlord-tenant dispute will be less likely to see the long-term benefits of participation. The need for organizing, which is present in all tenant involvement situations, will not have the added spur of owning the building to assist the landlord-tenant organizer. Moreover, since the effort to improve conditions through a rent strike is relatively short-lived (as opposed to the purchase and renovation of a building), the ability to train residents in the skills needed to perform is more limited. This is exacerbated by the paucity of lawyers who would be available for such efforts. Legal services and legal aid lawyers, even assuming they had the necessary skills, are already constrained by the press of caseloads. Will they be able to devote the needed time and effort to such esoterica?

I believe the results to date of tenant involvement warrant its continuation in ownership situations and in tax credit deals. I would like to see the model expanded into the friendly and not-so-friendly rental situations, as well. For that to happen there must be support from local governments. Among the policy changes that would support these efforts would be:

- the enactment of tenant opportunity to purchase statutes

- the provision of funds for purchase or for technical assistance

- a requirement that owners bargain in good faith with tenant associations

- an overall willingness to explore new and, perhaps, exotic methods to deal with the problems of inadequate and unaffordable housing.

With these policies in place and with a body of tenants and professionals willing to explore alternative housing strategies, there is a place for the concept of tenant involvement in the provision of decent, affordable housing that the residents, the owners, and the community can be proud of.

\section{Acknowledgements}

The author would like to thank my colleague and friend, Peter Byme, who provided great encouragement and support in the early stages of this project, and the participants in the Affordable Housing and Public-Private Partnerships: The Intersection of Housing, Property, and Real Estate workshop at the University of Colorado Law School. Robin Malloy and Nestor Davidson, in particular, provided valuable comments and assistance in the completion of this chapter. I also want to acknowledge the fine research assistance of Aaron Schmitz. 